\title{
CERMINAN KARAKTER ORANG SASAK DALAM NASKAH INDARJAYA
}

\section{THE REFLECTION OF SASAKNESE PEOPLES'S CHARACTERS IN MANUSCRIPT OF INDARJAYA}

\author{
Nuriadi \\ Universitas Mataram \\ Jalan Majapahit Nomor 62, Mataram, Kode Pos 83115 \\ Ponsel: 08121584261; Pos-el: nuriadi@unram.ac.id
}

\begin{abstract}
Abstrak
Artikel ini membahas cerminan karakter orang Sasak di dalam naskah Indarjaya Sasak. Penyajiannya dilakukan melalui metode kualitatif deskriptif dengan menggunakan teori strukturalisme dinamik sebagai pendekatan teoretisnya. Ditemukan enam karakter orang Sasak di dalam naskah Indarjaya, yaitu a. suka mengembara (ngambar); b. tekun (pacu/genem) mencari ilmu agama (sufisme); c. bersikap takzim dan berbahasa santun (tindih); d. kesatria atau pemberani(wanen/merang) demi harga diri; e. rendah hati; serta f. ramah dan terbuka (gerasaq). Semua karakter yang ditemukan ini merupakan karakter baik yang selalu dijunjung tinggi dan dikedepankan oleh masyarakat Sasak. Karakter-karakter ini menjadi identitas dan kebanggaan orang Sasak yang dipandang sebagai pembeda atau sebuah kekhasan dibandingkan dengan suku-suku lain di Indonesia.
\end{abstract}

Kata-kata Kunci: naskah Indarjaya Sasak; karakter orang Sasak; karya sastra lama

\begin{abstract}
This paper discusses a refelction of Sasak people's characters in the Sasak manuscript of Indarjaya. It is presented through a descriptive qualitative methodwith the use of dynamic structuralism as its theoretical framework. It is found that there are six Sasak people's characters in the manuscript, namely a. loving to wander (ngambar); b. being dilligent (pacu/genem) in seeking religious knowledge (sufism); c. respecting and politely speaking (tindih); $d$. being a knight or brave (wanen/merang) for intergrity; e. being humble; and f. being friendly and open (gerasaq). All of these characters are actually found in real Sasak communities as good characters and strongly recommendedto be actualized in the communities. These characters, therefore, serve as identity and pride for Sasak people by which they are different from other ethnic groups in Indonesia.
\end{abstract}

Keywords: Sasak manuscript of Indarjaya; Sasak people's characters; old literary work 


\section{Pendahuluan}

Etnis Sasak adalah salah satu etnis atau sukudi Indonesia yang berada di Pulau Lombok, sebuah pulau kecil di sebelah timur Pulau Bali. Belum bisa dipastikan sejauh ini sejak kapan suku bangsa ini mulai menghuni pulau kecil ini. Akan tetapi, dilihat dari karakter fisik, Sasak tidak jauh berbeda dengan sukuJawa, Bali, ataupun Melayu yang tersebar di Asia Tenggara umumnya dan yang ada di Indonesia bagian barat, Pulau Sumatera khususnya (Windia, 2006; Fadjri, 2015). Dengan kata lain, suku Sasak bisa dikatakan termasuk rumpun suku bangsa Melayu.

Suku Sasak, sama halnya dengan suku-suku yang lain di Indonesia, mempunyai khazanah kebudayaan atau kearifan lokal yang kaya (Fathurrahman, 2017). Hal itu salah satunya tercermin melalui karya "artefak" (seperti yang distilahkan oleh para strukturalis untuk karya sastra, bukan istilah "ojyek estetis") berupa karya-karya sastra Sasak yang kemudian dapat digolongkan sebagai karya sastra lama. Orang Sasak mengenal tiga macam sastra lama, yaitu Babad, Serat, dan Suluk. Semua naskah sastra lama tersebut umumnya ditulis dalam bahasa dan aksara Kawi atau Jejawan, meskipun terdapat pula yang menggunakan bahasa Melayu. Naskah-naskah Babad adalah
Babad Praya, Babad Selaparang, Babad

Sakre, dan Babad Lombok. Contoh naskah Serat Sasak, yakni Puspekarme, Indarjaye, Jatisuare, Labangkare, Duwarsah, Megantake, Raresigar, Bangbari, Jonglengge, Kabarsundari, Serat Menak, dan sebagainya. Sementara itu, contoh naskah sastra lama berupa Suluk adalah Manusie Jati, Dalang Jati, Suluk Nukat, Bayan Alif, Tapal Adam, Markum, dan sebagainya. Dengan demikian, masyarakat Sasak mempunyai banyak khazanah kesastraan yang dapat menjadi inspirasi dalam membangun Sasak sebagai suku bangsa beradab.

Semua teks sastra lama itu masih hidup dan berkembang sampai saat ini dalam bentuk kegiatan memaos meskipun persentase peminatnya sudah mulai berkurang. Hal itu terbukti dari keberlangsungannya yang hanya berada di daerah dan waktu tertentu saja, seperti di wilayah Lombok Tengah dan pada acara pesta perkawinan saja. Kebertahanannya hingga saat disebabkannilai estetik dan afektif yang dapat dinikmati oleh masyarakat. Dengan kata lain, dapat diasumsikan bahwa sastra lama yang disebut di atas mempunyai peran yang cukup strategis dalam membentuk karakter masyarakat Sasak sehingga khas dan berbeda dengan karakter suku-suku bangsa lainnya. Hal ini dikarenakan hampir semua 
cerita dalam naskah sastra di atas mengandung pesan moral yang berkaitan erat dengan nilai dan ajaran agama Islam, khususnya yang bersumber dari Al-Quran dan Al-Hadist.

Pengkajian terhadap naskah lama Sasak ini cukup perlu dilakukan. Hal ini disebabkan karena pemerintah, melalui Kementerian Pendidikan dan Kebudayaan, mencanangkan pendidikan karakter. Keberadaan naskah sastra lama, seperti Indarjaya, Labangkara, atau Duarsah dan yang lainnya dinilai memiliki kontribusi dalam membentuk karakter masyarakat Sasak. Naskah sastra lama ini sebenarnya mengandung nilai pembelajaran moral ataupun sosial bagi kehidupan masyarakat, khususnya bagi generasi muda atau anakanak Sasak. Penemuan nilai-nilai tersebut dapat dilakukan dengan melakukan pengkajian dan penelitian. Oleh karena itu, dipandang perlu untuk mengkaji isi yang terkandung di dalam salah satu naskah sastra lama, yaitu Indarjaya Sasak.

Alasan mengapa naskah Indarjaya Sasak yang diangkat, tidak naskah lainnya. Pertama, naskah Indarjaya Sasak ini dikenalsebagai rujukan para tetua-tetua Sasak ketika melakukan pembicaraan yang berkaitan dengan tata cara dan perilaku yang luhur. Tata cara dan perilaku yang luhur tersebut tentu secara lebih khusus berkaitan langsung dengan ajaran agama.
Sebagaimana diketahui umum bahwa naskah sastra lama, termasuk naskah Indarjaya, ditulis oleh penulisnyasebagian besar anonim-dalam rangka memberi ajaran kebaikan dan kebajikan sebagaimana disampaikan di dalam ajaran agama, utamanya agama Islam yang menjadi agama mayoritas masyarakat Sasak.

Kedua, meskipun naskah Indarjaya Sasak dan naskah lainnya mempunyai kandungan nilai yang baik, tidak banyak masyarakat (khususnya generasi muda) Sasak mengetahuinya. Mereka lebih mengenal karya-karya sastra baru, kontemporer, dan kebarat-baratan daripada karya atau naskah yang merupakan peninggalan para leluhur Sasak. Hal ini tentu sangat ironis dan menyedihkan. Oleh karena itu, pengkajian terhadap naskah Indarjaya Sasak ini berperan sebagai langkah awal di dalam memopulerkan naskah tersebut, termasuk dengan isi yang dikandungnya. Upaya yang kecil ini diharapkan bisa menjadi langkah awal untuk menggali dan merevitalisasi warisan (local genius) para leluhur masyarakat Sasak sehingga kearifan lokal (local wisdom) yang dikandungnya bisa terus hidup di tengah gempuran nilai, pandangan hidup, serta sikap perilaku yang global dan sekuler. Ahimsa-Putra (2009) pernah mengatakan bahwa sastra lama dari daerah 
pada dasarnya cukup sarat dengan kearifan lokal yang luhur.

Ada tiga hasil penelitian sebelumnya yang berkaitan dengan karakter orang Sasak dan Kitab Indarjaya, yaitu (a) penelitian Nuriadi (2018); (b) Penelitian Suranggana (2006); dan (c) PenelitianIstanti (1985). Pertama, Nuriadi (2008) dalam penelitiannya menemukan sejumlah pemikiran umum yang muncul dalam sembilan belas lirik lagu yaitu: a. kesedihan, b. ketakberdayaan perempuan, c. ungkapan kekaguman pada seseorang, d. ungkapan jatuh cinta dan perjuangannya, e. kerinduan pada kekasih, f. nasihat, g. ingkar janji/pengkhianatan, h. pelajaran hidup, i. vulgaritas nafsu, j. ungkapan kebesaran Tuhan atas Gumi Sasak, k. doa dan penghormatan pada orang tua, serta 1 . perubahan zaman. Kedua, Suranggana (2006) melakukan pengkajian dari dua sudut pandang teori, yaitu teori filologi dan teori semiotik. Hasil penelitian ini menunjukkan bahwa Indarjaya merupakan naskah sastra lama yang tidak hanya berkembang di masyarakat Sasak, tetapi juga berkembang di beberapa daerah di Nusantara. Selain itu, dari penelitian ini juga ditemukan bahwa naskah Indarjaya, dari sudut pandang semiotis, mengandung simbol-simbol yang sarat dengan ajaran sufistik. Ketiga, sejalan dengan yang temuanSurenggana (2006), hasil temuan
Istanti (1985) juga menunjukkan bahwa naskah Indarjaya merupakan karya sastra lama berupa suluk yang membahas persoalan sufisme, sebagai bentuk awal persebaran agama Islam di tanah Jawa khususnya dan seluruh wilayah Nusantara umumnya. Dengan demikian, naskah Indarjaya Sasak bisa dipandang sebagai bagian dari wahana persebaran agama Islam di Pulau Lombok

Terkait dengan hal di atas, artikel ini bermaksud menjawab rumusan masalah yang berkaitan dengan nilai karakter yang direfleksikan dalam kitab Indarjaya Sasak. Rumusan masalah tersebut tertuang dalam pertanyaan, “Apa sajakah ragam karakter yang tercermindalam naskah Indarjaya yang sejauh ini dipandang luhur oleh masyarakat Sasak?"

\section{Landasan Teori}

Karya sastra, dalam pandangan teori strukturalisme dinamik, berperan sebagai objek estetis (aesthetic object) sebagaimana dikemukakan Mukarovsky dan Felix Vodicka. Hal itu dikarenakan karya sastra mempunyai makna atau nilai yang bisa bermanfaat bagi masyarakat selama bisa dikonkretisasi, diapresiasi, atau ditafsirkan terus-menerus secara dinamis. Dalam proses ini pembaca sastra tidak boleh menggunakan sudut pandang positivistik sebagaimana yang biasanya 
dilakukan kaum strukturalis. Pembaca sastra harus menggunakan pandangan yang holistik dengan melibatkan berbagai sumber perspektif, baik dari pembaca, pengarang, situasi sosial masyarakat, maupun karya itu sendiri (Nuriadi, 2016).

Strukturalisme dinamik lebih merupakan pengembangan strukturalisme murni atau klasik. Strukturalisme dinamik mengakui kesadaran subjektif dari pengarang dan juga mengakui peran sejarah serta lingkungan sosial. Meskipun demikian, pusat penelitian tetap pada karya sastra itu sendiri. Perbedaan pokok antara strukturalisme genetik dan dinamik terletak pada subjek yang diteliti. Strukturalisme dinamik lebih menekankan pada karya-karya masterpiece, karya mainstream, dan karya agung (Endraswara, 2013:62).

Strukturalisme dinamik lebih fleksibel dalam menerapkan teori penelitian jika dibandingkan dengan strukturalisme murni. Teori yang dipakai biasanya merupakan gabungan sedikitsedikit antara teori satu dengan yang lain. Penelitian ini menolak asumsi-asumsi strukturalisme murni yang sangat tidak menerima kesadaran subjektif, takluk pada sistem, menolak historisisme, mengidolakan sinkronik, dan antihumanisme. Atas dasar ini, strukturalisme dinamik justru mengenalkan penelitian sastra dalam kaitannya dengan sistem tanda. Caranya adalah dengan menggabungkan kajian otonom karya sastra dan semiotik. Kajian otonom yang dilakukan secara intrinsik dan semiotik akan mempresentasikan teks sastra sebagai ekspresi gagasan, pemikiran, dan cita-cita pengarang. Gagasan tersebut dimanifestasikan dalam tanda-tanda khusus. Kepaduan antara struktur otonom dan tanda ini merupakan wujud yang menunjukkan bahwa struktur karya sastra bersifat dinamis.

Kedinamisan kajian struktur sastra tersebut disebabkan oleh kreativitas pembaca. Pembaca adalah makhluk yang mampu masuk ke dalam ruang-ruang dan memberi tanda yang bermakna. Oleh karena itu, peneliti strukturalisme dinamik sekurang-kurangnya memiliki dua tugas, yaitu (1) menjelaskan karya sastra sebagai struktur berdasarkan unsur-unsur yang membentuknya dan (2) menjelaskan kaitan antara pengarang realitas, karya sastra, dan pembaca (Sayuti dalam Taum 1997:89). Dari paradigma semacam ini sebenarnya strukturalisme dinamik hampir dekat dengan strukturalisme genetik. Hanya saja, keduanya memiliki penekanan yang sedikit berbeda. Jika strukturalisme genetik mengaitkan asal-usul kelahiran sastra, maka strukturalisme dinamik menekankan relasi struktur dengan realitas. 
Dengan memahami konsep teoritis strukturalisme dinamik di atas, keberadaan naskah Indarjaya sebagai sebuah karya sastra menjadi semakin menarik untuk dikaji. Artinya, dengan teori strukturalisme ini naskah dibedah dalam rangka melihat makna dan perannya dalam membangun masyarakat yang dicerminkannya, dalam konteks ini adalah masyarakat Sasak. Strukturalisme dinamik, dalam hal ini, mensyaratkan hadirnya perspektif dari ranah pembaca, latar belakang sosial, maupun pengarang. Meskipun demikian, ranah karya tentu menjadi sumber primer. Oleh karena itu, penggunaannya dalam sajian artikel ini mengarah kepada sajian holistik yang tidak hanya menyajikan data dari karya itu saja, tetapi juga melakukan penguraian dengan menggunakan data dari ranah pembaca serta latar belakang sosialbudaya dan historis tempat karya ini muncul dan berkembang.Dengan model ini diharapkan pemaknaan terhadap naskah Indarjaya menjadi komprehensif dan argumentatif.

\section{Metode Penelitian}

Artikel ini menggunakan metode kualitatif-deskriptif (Strauss dan Corbin, 2003). Metode ini sebenarnya diterapkan pada dua tahap, yaitu tahap pengumpulan data dan tahap penganalisisan data.Pada tahap pertama, metode kualitatif ini diderivasi dalam pengumpulan data secara kepustakaan dan lapangan.Dalam konteks kepustakaan, penulis menggunakan teknik pengodean, parafrase, dan pengutipan secara langsung pada naskah Indarjaya ketika menentukan dan mengategorisasi data primer.Sementara itu, dalam konteks pengambilan data di lapangan atau masyarakat, penulis melakukan wawancara pada subjek penelitian dan melakukan observasi berkaitan dengan karakter orang Sasak.

Di samping itu, pada tahap penganalisisan data, metode ini mensyaratkan supaya sajian makalah dipresentasikan menggunakan kata-kata, narasi, deskripsi dan argumentasi, bukan dalam wujud sajian data yang berbentuk numerik ataupun statistik (Holliday, 2002).Selain itu, menurut Creswell (1998), sajian data dengan metode ini seharusnya diambil dari data lapangan yang mencerminkan setting yang jelas dan jernih. Oleh karena itu, makalah ini berusaha menyajikan data dan laporan yang bersesuaian dengan konsep dasar metode kualitatif dan deskriptif yang dimaksud di atas.

Melalui penggunaan metode kualitatif-deskriptif jelaslah bahwa masyarakat Sasak diposisikan sebagai lingkup setting sosial dan budaya dari ranah pembaca dan ranah latar belakang 
sosial kemasyarakatan terhadap karya. Masyarakat Sasak merupakan real setting yang menjadi sumber data dan informasi yang menjadi bahan elaborasi kajian naskah. Singkatnya, informasi dari naskah dan dari masyarakat ditriangulasi secara tematik dalam rangka menyuguhkan seperti apa dan sejauh mana karakter orang Sasak.

\section{Pembahasan}

Dalam Kitab Indarjaya versi Sasak ini terdapat enam karakter orang/suku Sasak yang ditemukan dan diakui masih berkembang sampai saat ini sebagai kebanggaan atau identitas orang Sasak. Enam karakter itu adalah (a) suka mengembara (ngambar), (b) tekun (pacu/genem) mencari ilmu agama, (c) bersikap takzim dan berbahasa santun (tindih), (d) kesatria atau pemberani(wanen/merang) demi harga diri, (e) rendah hati,serta (f) ramah dan terbuka (gerasaq).

\subsubsection{Suka Mengembara (Ngambar)}

Yang dimaksud dengan suka mengembara (ngambar) adalah sebuah karakter yang memperlihatkan suka meninggalkan rumah, keluarga, atau kampung halaman ke tempat-tempat asing dengan maksud atau tujuan tertentu. Aktivitas seperti ini dilakukan secara perseorangan dengan menggunakan fasilitas dan bekal yang apa adanya, bahkan tidak ada.

Gambaran karakter orang Sasak yang suka mengembara ini tercermin seperti dilakukan oleh dua tokoh dalam naskah Indarjaya, yaitu Komala Ratna Sudewi dan Sahi Merdan. Tokoh pertama, perempuan yang ternyata merupakan anak seorang raja Darul Marjum, melakukan pengembaraan seorang diri karena terpisah dari teman-temannya. Bepergian sendiri bagi perempuan Sasak tidaklah lazim, tetapi hal ini bisa terjadi dikarenakan situasi atau kondisi tertentu. Berikut adalah kutipan yang memperlihatkan hal dimaksud.

41. Wahai sebab hamba begini sendiri tiada teman, hamba anak raja besar Ratu Darul Marjum, ada pun hamba ini bernama

42. Komala Ratna Sudewi, hamba pergi bersenang-senang mandi di kebun bersama inang pengasuh, berwisma para dayang-dayang muda. Sesampai di taman, hamba bersama-sama mereka pun mandi di pancuran.

43. Setelah kami mandi, mereka memetik bunga-bunga yang harum. Ada pula yang memetik buah-buahan, durian manggis, jeruk, duku, rambutan, jambu. Ramai mereka berebutan.

44. Sendirian hamba ditinggalkan, lalu datang raksasa betina bersayap. Disambarnya hamba ke atas, diterbangkan ke 
angkasa, serta dijadikanlah hamba sebagai anak angkatnya (Kitab Indarjaya, bait 41-44).

Sementara itu, Sahi Merdan yang kemudian bernama Indarjaya melakukan pengembaraan disebabkan karena terdorong untuk mencari ilmu. Pengembaraannya merupakan sebuah keniscayaan dan tidak dilarang oleh orang tuanya. Dia melakukannya demi mencari ilmu sejati dan kesaktian. Oleh karena itu, kenikmatan duniawi yang seharusnya dinikmati, tidak menjadi penghalang atas niat dan tekadnya untuk melakukan pengembaraan. Buktinya, meskipun baru saja menjadi menikah dengan wanita cantik, puteri raja Darul Marjum, Sahi Merdan tetap meninggalkan situasi tersebut sebagaimana tergambar pada dua bait berikut.

79. Sahi Merdan lalu berujar, "Wahai sayangku, hamba mohon diri sayangku, hamba berangkat hari ini, hamba akan mencari ilmu, masih banyak yang aku tak tahu". Puteri lalu menjawab, "Mengapa demikian cara kanda berumah tangga dengan hamba, tak tahan hamba ditinggalkan, apalagi hamba sedang hamil".

80. Sahi merdan tersenyum menjawab, "Wahai sayangku, hamba pergi hanya sebentar, hamba akan pulang dan apabila telah lahir puteri lelaki, namai ia Indardewa, bila anak wanita lahir, beri nama sesukamu". Sambil mencium bibir dan pipinya berulang, ia pun berangkat (Kitab Indarjaya, bait 79-80).

Karakter suka mengembara ini sebenarnya dilakukan oleh para leluhur orang Sasak pada zaman dahulu. Pengembaraan yang umumnya dilakukan orang muda tersebut dilaksanakan karena tiga faktor atau alasan. Pertama, untuk mendapatkan ilmu kesaktian dengan harapan menjadi orang yang lebih disegani dan dihormati setelah kembali sebagaimana dilakukan anak muda Sasak sekarang ini yang pergi sekolah (mondok atau ngamarin) ke daerah lain atau ke sejumlah kiai/tuan guru. Kedua, untuk mendapatkan harta sebagai modal meningkatkan taraf hidup dan kehidupan keluarga yang lebih baik sebagaimana umumnya dilakukan oleh orang Sasak, yakni menjadi TKI atau TKW ke Arab Saudi, Bahrain, Uni Emirat Arab, Malaysia, Taiwan, Hongkong, Singapura, dan sebagainya. Ketiga, untuk membuktikan diri bahwa orang Sasak adalah orang-orang yang pemberani, percaya diri, dan dewasa. Orang-orang Sasak yang telah melakukan pengembaraan biasanya lebih bersikap dewasa dan percaya diri menghadapi persoalan hidup. Dengan demikian, orang Sasak memandang bahwa mengembara 
merupakan salah satu cara menjadikan manusia Sasak menjadi lebih baik.

\subsubsection{Tekun (Pacu/Genem) Mencari Ilmu Agama}

Sahi Merdan atau Indarjaya sebagai

tokoh utama dalam naskah Indarjaya merupakan sosok yang mempunyai ketekunan dalam mencari ilmu. Dia adalah orang yang senantiasa merasa kekurangan terhadap ilmu pengetahuan. Meskipun mempunyai ilmu kesaktian tinggi yang diajarkan orang tuanya, Sahi Merdan tetap meninggalkan rumah atau istana kerajaan dikarenakan merasa belum puas terhadap ilmu yang dimilikinya.Ilmu yang dicari bukanlah ilmu kedigdayaan duniawi saja, melainkanjuga ilmu agama atau ilmu yang bisa mengantarkan dirinya untuk selalu dekat kepada Yang Maha Pencipta, Allah Swt.

Sikap yang tekun mencari ilmu sejati itu terlihat pada peristiwa ketika Sahi Merdan belajar ilmu agama pada Syekh Salamudin sebagaimana diceritakan mulai bait 84 sampai dengan bait 90 . Pada tahap pencarian ini Sahi Merdan mendapat ilmu yang cenderung masih bersifat syariati. Ilmu ini intinya membentuk karakter kemanusiaan Sahi Merdan sebagai orang yang baik. Adapun ilmu yang diajarkan terlihat pada kutipan berikut.

87. Janganlah engkau berbuat jahil, menjalankan syariat agar berhati-hati, janganlah ananda iri hati, janganlah memperdaya orang, mengadu domba orang sangatlah tabu, bila ananda difitnah janganlah risau, baik buruknya ananda berserah kepada Allah serta santunlah kepada si miskin dan kyai yang tidak tamak. (Kitab Indarjaya, bait 87).

Ketekunan (pacu/genem) Sahi Merdan di dalam mempelajari ilmu agama terlihat lagi pada peristiwa lain, yakni dalam lanjutan pengembaraannya setelah meninggalkan guru Syekh Salamudin. Pada bagian selanjutnya Sahi Merdan bertemu dengan guru berikutnya yang bernama Syekh Lukmanul Hakim (Kitab Indarjaya, bait 98). Sahi Merdan merupakan murid Syekh Lukmanul Hakim yang ke-40.

Ilmu agama yang diperolehnya dari Syekh Lukmanul Hakim jauh lebih serius atau mendalam daripada apa yang sudah dipelajarinya ketika masih berguru pada Syekh Salamudin. Ilmu agama yang dipelajarinya adalah ilmu sufisme yang menitikberatkan pada "penyatuan diri" manusia sebagai makhluk dengan Allah Sang Pencipta. Pengajaran Syekh Lukmanul Hakim kepada Sahi Merdan ini terlihat secara eksplisit pada bait-bait Kitab Indarjaya dari bait 102 sampai dengan bait 171. Atas ketekunan dan semangatnya belajar agama inilah kemudian Syekh Lukmanul Hakim 
menyebut atau mengganti nama Sahi Merdan menjadi "Indarjaya". Berikut adalah penggalan dialog Sahi Merdan (Indarjaya) dengan Syekh Lukmanul Hakim yang membuktikan bahwa ajarannya adalah sufisme.

123. Indarjaya berucap takzim, "Hamba mohon sesungguhnya yang dimaksud syariat, tarekat, hakikat, dan makrifat itu, di mana kedudukannya satu persatu pada tubuh kita agar hamba mewaspadai?"

124. "Anakku Indarjaya, yang bernama syariat perkataan, tarekat itu perbuatan, hakikat itu kenyataan, dan yang disebut makrifat itu mengetahui hakikat ilmu". Indarjaya itu menyembah sambil berkata, "Kedudukan syariat, tarikat, hakikat, dan makrifat itu di mana?"

125. "Wahai anakku Indarjaya, tempat syariat pada lidah, tempat tarekat pada hati, hakikat tempatnya di bumi, dan makrifat tempatnya pada rahasia, itulah empat perkara di dalam raga kita ini." Indarjaya pun berkata, "Hamba junjung pengajaran Tuan" (Kitab Indarjaya, bait 123-125).

Ketekunan Sahi Merdan atau Indarjaya ini terlihat sekali ketika berguru kepada Syekh Lukmanul Hakim. Dia mempelajari dan meresapi semua ilmu yang diberikan sampai benar-benar merasa puas dan menguasai setiap ajarannya.
Artinya, terkait dengan karakter Sasak, ketekunan mempelajari agama ini sebenarnya sudah menjadi kebiasaan orang Sasak secara umum. Hal ini diperlihatkan dari pandangan bahwa orang Sasak akan dinilai memalukan apabila tidak bisa membaca Al-Quran. Sebaliknya, orang yang bisa menjadi "tuan guru" akan dinilai sebagai kebanggaan keluarga. Sebagian besar orang Sasak bahkan berpandangan bahwa ilmu agama jauh lebih penting daripada ilmu umum. Oleh karena itu, tidak mengherankan apabila anak-anak telah diajarkan agama sejak usia dini dan bersekolah di madrasah terkenal di Indonesia maupun di Timur Tengah.

\subsubsection{Bersikap Takzim dan Berbahasa Santun (Tindih)}

Takzim atau menunjukkan sikap hormat, patuh, dan tunduk pada kata-kata orang tua dan guru adalah sikap yang terpuji. Sikap takzim dengan menggunakan bahasa yang santun dalam bahasa Sasak disebut dengan istilah tindih. Sikap ini merupakan hasil dari didikan atau pembelajaran karakter melalui ilmu agama. Hal itu sangat dianjurkan, bahkan diwajibkan, dalam agama Islam. Sikap takzim yang mendarah daging pada diri seseorang menunjukkan bahwa pembelajaran ilmu agamanya berhasil dan ilmu yang sudah diperoleh akan selalu berkah dan bermanfaat bagi diri sendiri 
dan masyarakat luas. Sebaliknya, jika sikap takzim pada orang tua dan guru tidak dilakukan maka orang tersebut dianggap durhaka dan ilmu yang diperolehnya tidak berkah atau tidak bermanfaat. Oleh karena itu, sikap seperti ini sangat dianjurkan dan ditradisikan sejak awal atau sejak kecil dalam kehidupan sehari-hari, baik di sekolah ataupun di rumah.

Sikap patuh atau takzim pada guru dan orang tua diperlihatkan secara jelas oleh hampir semua karakter protagonis di dalam cerita Kitab Indarjaya. Hal itu diperlihatkan Sahi Merdan atau Indarjaya ketika berhadapan dengan guru-guru dan orang tuanya.Sikap takzim ini ditunjukkan melalui dua hal, yaitu sikap/perilaku dan tutur kata.Untuk lebih jelasnya, berikut ini kutipan-kutipan yang menunjukkan sikap takzim yang ditunjukkan Sahi Merdan sebagai tokoh utama dalam naskah Indarjaya.

20. Brahmana lalu berganti pakaian, kemudian diperciki minyak harum oleh gadis-gadis remaja muda belia. Sahi Merdan memohon:"Brahmana hamba memohon ilmu kesaktian ilmu kesaktian yang tinggi, dan ilmu kewibawaan berikan hamba.

21. Akuilah hamba sebagai anak kandung!" Brahmana kemudian menjawab, "Sesuka Tuan, hamba tiada keberatan, besar kebaktian hamba mengabdi." Dia pun lalu diajarkan ilmu kesaktian. Arkian lamanya dia belajar tiga bulan lamanya.

85. Ki Syekh Salamuddin mendengar dengan perasaan sangat iba, "Di sini engkau duduk bersanding." Indarjaya berhatur sembah, naik lalu duduk bersama. Di hadapan mereka tersaji umbi dan keladi yang sudah masak direbus. "Inilah nanda makan keladi dan ubi!" Perintah sang Syekh. Lalu Indarjaya permisi untuk menikmati ubi dan keladi tersebut. (Kitab Indarjaya, bait 20, 21, dan 85).

Dari kutipan (bait 20, 21, dan 85) di atas terlihat jelas sikap takzim atau hormat Sahi Merdan kepada dua gurunya, yaitu Brahmana dan Syekh Salamuddin. Bukti sikap ketakziman itu terlihat dari pilihan kata "memohon" (bait 20), dan klausa "Indarjaya berhatur sembah", serta kata "permisi" atau mohon izin (bait 85). Sikap takzim ini menjadikannya semakin diperhatikan dan dicintai sehingga ilmu yang ditimba kepada kedua guru itu dapat dikuasai secara cepat. Hal ini menandakan bahwa ketakziman kepada guru merupakan titik awal menjadikan ilmu itu berkah. Penghormatan pada guru hukumnya wajib.

Sementara itu, sikap takzim (tindih) yang ditunjukkan Sahi Merdan kepada orang tuanya terlihat ketika tidak menolak atau tidak berkeluh kesah ketika diperintahkan untuk berjuang keras 
menguasai semua ilmu yang seharusnya dikuasai sebagai anak raja (lihat bait 13).

Dalam konteks ini Sahi Merdan menunjukkan kepatuhan sekaligus ketakziman kepada ayahnya. Selain itu, meskipun sudah menikmati pengembaraan selama bertahun-tahun, Sahi Merdan tetap ingat kampung halaman yang meminta dirinya menjadi raja, melanjutkan dinasti ayahnya. Tindakan ini secara implisit menunjukkan bahwa Sahi Merdan patuh pada perintah ayahnya. Sikap takzim ini tentu selalu ditunjukkan juga kepada orang lain seperti mertuanya. Dia selalu menggunakan kata-kata sopan dengan sikap tunduk kepadanya sebagaimana terlihat pada kutipan berikut.

368. Pergi keduanya lalu tiba dan menghormati pada ayah bundanya, "Ada apa keperluan nanda wajah kalian tampak muram?" Indarjaya berhatur takzim, "Ampun, keperluan hamba menghadap Tuanku.

369. "Hamba mohon diri bersama dengan puteri Tuanku. Kami akan pergi menjenguk besan Tuanku di negeri Darul Astan.” Sudah dituturkan semua tingkahnya (Kitab Indarjaya, bait 368 - 369).

Dengan demikian, sehubungan dengan fakta di atas, para orang tua orang Sasak sangat menekankan hadirnya adab dan bahasa yang baik (tindih) ditanamkan kepada generasi muda Sasak. Ketakziman (tindih) ini merupakan salah satu identitas Sasak, selain ilaq, maliq, dan merang. Hal ini menandakan bahwa Sasak merupakan bangsa yang sudah tua dan mempunyai ciri khas yang baik dalam karakternya. Implikasi dari ajaran para orang tua pada anak-anak Sasak adalah ketidakberanian untuk membantah atau selalu tunduk dan patuh pada perintah orang tua. Bagi anakanak Sasak, sikap membantah atau membangkang pada orang tua adalah tindakan tidak terpuji dan diyakini bisa mendatangkan malapetaka bagi diri sendiri (tulah manuh).

\subsubsection{Kesatria atau Pemberani (Wanen/Merang)}

Kesatria adalah sikap kepahlawanan seseorang yang dilandasi keberanian menegakkan kebenaran yang diyakini serta menjaga nama baik, kehormatan, dan harga diri. Sikap kesatria ini biasanya ditunjukkan dalam wujud sikap berani, tegas, dan tidak merasa takut menghadapi setiap ancaman atau tantangan yang muncul dari luar diri dan kelompoknya. Sikap kesatria yang wujudnya berupa keberanian ini dalam bahasa Sasak disebut wanen. Sikap tersebut kemudian ditunjukkan dengan perilaku siap melawan dan tidak ada rasa takut berhadapan dengan musuh yang dalam bahasa Sasak disebut dengan istilah 
merang. Kedua istilah ini dimiliki oleh hampir semua orang Sasak dikarenakan mereka sangat menjaga kehormatan diri. Salah satu cara di dalam menjaga kehormatan itu adalah dengan sikap wanen dan merang tersebut. Dengan kata lain, orang Sasak akan menjadi tidak berharga dan dipandang rendah apabila bersikap pengecut terhadap persoalan yang dihadapi. Sikap kesatria dalam wujud wanen dan merang merupakan sikap tanggung jawab terhadap diri dan kelompok. Oleh karena itu, orang Sasak bersikap "lebih baik mati" daripada tidak terhormat dan dinilai pengecut oleh orang lain.

Kehormatan diri adalah hal yang paling dijunjung tinggi oleh orang Sasak. Untuk menunjukkan hal itu, sikap wanen dan merang benar-benar ditanamkan sebagai sebuah karakter dasar yang harus dimiliki oleh orang Sasak. Karakter atau sikap ini umumnya ditunjukkan dalam bentuk tindakan berupa keberanian orang Sasak beradu tanding atau berperang di medan peperangan yang sejauh ini diekspresikan melalui seni tari peresean.

Dalam konteks ini, refleksi atau cerminan sikap wanen dan merang ini sangat tergambar jelas dalam cerita naskah Indarjaya. Bukti literer dari sikap tersebut ditunjukkan dalam beberapa peristiwa berikut. Pertama, Sahi Merdan atau
Indarjaya menunjukkan sikap kesatria melawan garuda sebagaimana terlihat dalam kutipan berikut.

397. Indarjaya pun segera memanahnya, garuda itu terkena lehernya dan terjatuh ke tanah, Indarjaya bersiap cepat memindahkan nyawanya sendiri ke dalam bangkai garuda. (Kitab Indarjaya, bait 397).

Kedua, sikap kesatria atau keberanian dalam berperang ditunjukkan oleh Indardewa dan Indarlelana yang sebenarnya adalah anak dan calon anak ipar dari Indarjaya. Artinya, kesaktian Indarjaya sudah jauh di atas kedua tokoh disebut. Kedua tokoh ini berperang tanding tanpa rasa takut. Sebagai buktinya dapat dilihat pada kutipan-kutipan berikut.

569. "Hai Sahi Merdan takutkah kau melawanku berperang sehingga kamu berlindung?" Indardewa cepat naik di mahkota emas, mahkota sang naga sambil berteriak.

570. "Hai Indarlelana habiskan kesaktianmu keluarkan!" Indarlelana menjawab, "Beritahukanlah aku namamu, asal ayahmu yang sebenarnya, dan siapa nama ayahmu. Sayang kamu akan mati”.

571. "Pergilah engkau. Kasihan engkau masih bocah!" Indardewa menyahut sambil tertawa menantang, "Jangan 
engkau banyak bicara, ayo kita perang tanding kesaktian!” Indarlelana memanah dengan run api.

572. Seperti gunung besarnya menuju Indardewa. Indardewa segera melepas panah hujan, Indarlelana melepaskan runpanah menjadi aneka macam hewan (Kitab Indarjaya, bait 569-572).

Fakta-fakta literer yang ditunjukkan dalam naskah Indarjaya ini menunjukkan secara gamblang bahwa para tokoh di dalam kitab tersebut adalah kesatria. Semua tokoh laki-laki di dalam kitab tersebut mempunyai sikap yang kesatria. Ini menunjukkan bahwa mempunyai karakter yang kesatria, wanen dan merang, merupakan karakter penting dan wajib sebagai laki-laki, khususnya laki-laki Sasak. Sikap itu menunjukkan eksistensi seseorang untuk bisa dihargai.

\subsubsection{Bersikap Rendah Hati}

Meskipun diajarkan untuk berwatak wanen atau merangdalam kehidupannya, orang Sasak oleh para leluluhurnya tetap diajarkan untuk senantiasa rendah hati. Rendah hati merupakan sikap dan/atau karakter yang terpuji sehingga setiap orang tua senantiasa menanamkan kepada anaknya untuk selalu rendah hati, tidak boleh sombong atau congkak kepada orang lain.
Sikap rendah hati merupakan ajaran terpuji dari semua agama, terutama agama Islam. Dalam Al-Quran Surat alFurqan ayat 63, Allah berfirman yang artinya "Dan hamba-hamba Tuhan yang Maha Penyayang itu (ialah) orang-orang yang berjalan di atas bumi dengan rendah hati dan apabila orang-orang jahil menyapa mereka, mereka mengucapkan kata-kata (yang mengandung) keselamatan”. Selain itu, Rasulullah Saw. pun pernah bersabda terkait sikap rendah hati yang artinya "Sesungguhnya Allah telah mewahyukan kepadaku untuk menyuruh kalian bersikap rendah hati sehingga tidak ada seorang pun yang membanggakan dirinya di hadapan orang lain, dan tidak seorang pun yang berbuat aniaya terhadap orang lain" (HR. Muslim diunduh dalam www.tongkronginislami.net).

Firman dan hadis tersebut menunjukkan dengan jelas bahwa sikap rendah hati adalah perintah agama. Jika sikap sombong dan aniaya tertanam dalam diri, maka hal itu menunjukkan seseorang telah ingkar pada ajaran agama Islam. Sebagaimana diketahui bahwa orang Sasak sebagian besar adalah beragama Islam. Oleh karena itu, jika dikaitkan dengan firman dan hadis di atas,orang Sasak harus bersikap rendah hati. Bisa dikatakan bahwa karakter Sasak yang paling 
mendasar itu adalah rendah hati. Jika sikap itu tidak tertanam dalam diri orang Sasak, bisa dikatakan bahwa orang itu bukanlah orang Sasak yang sebenarnya. Sikap rendah hati adalah sikap tawaduk yang merupakan intisari dalam ajaran tarekat. Sikap itu dilakukan oleh kaum salik (orang sufi) dan diajarkan juga dalam kitab suluk.

Penggambaran terkait rendah hati ini sangatlah jelas di dalam Kitab Indarjaya. Sebagaimana diketahui sebelumnya, kitab ini merupakan salah satu kitab suluk yang berkembang di masyarakat Sasak. Oleh karena itu, tidak mengherankan apabila sikap rendah hati ini juga ditunjukkan atau digambarkan di dalam kitab tersebut. Sikap rendah hati atau tawaduk merupakan syarat mutlak untuk menguasai ilmu tarekat atau sufisme, selain sikap tekun dan setia.Sikap ini dalam masyarakat Sasak menjadi salah satu sikap yang dikategorikan sebagai sikap tindih.

Ada dua cara para tokoh utama, khususnya Sahi Merdan (Indarjaya) dalam menunjukkan karakter kerendah-hatian ini, yaitu (a) melalui tutur kata dan (b) dengan sikap-perilaku. Adapun bukti di dalam Kitab Indarjaya yang menunjukkan sikap rendah hati sebagai berikut.

131. Indarjaya matur sembah, "Tuan, hamba berguru lagi. Apakah nama nyawa syariat, tarikat, dan nyawa makrifat itu?" Tuan syekh menjawab, "syariat nyawanya nafsu ulamah, nyawa tarikat. (kitab Indarjaya, bait 131).

Kutipan di atas memperlihatkan secara jelas sikap dan perkataan Sahi Merdan yang cukup rendah hati, memosisikan dirinya sebagai orang yang tidak tahu-menahu persoalan ajaran agama tasawuf. Sikap merendah atau rendah hati itu tergambar dengan dua pernyataan: "Indarjaya matur sembah..." dan "Tuan, hamba berguru lagi”. Kedua pernyataan ini menunjukkan sikap Sahi Merdan yang sangat rendah hati, tidak menunjukkan kesombongan kepada orang lain yang kebetulan menjadi gurunya.

445. "Mengapa Tuanku tiada berterus terang kepada ayahanda mengapa tiada memaklumkan bahwa ananda putera raja?" Sahi Merdan menyembah, "Memohon ampun beribu ampun Tuanku, amatlah malu hamba, memperkenalkan diri hamba" (Kitab Indarjaya, bait 445).

Kutipan bait 445 di atas makin mempelihatkan bagaiamana karakter rendah hati itu sudah tertanam kuat di dalam batin Sahi Merdan sebagai pelaku sufi. Dia merasa malu untuk menunjukkan dirinya yang sebenarnya sebagai anak raja kepada orang lain. Sikap malu ini 
merupakan hasil dari ilmu agama yang sudah dikuasainya. Meskipun demikian, sikap Sahi Merdan yang diketahui cenderung menyembunyikan identitas tersebut justru menjadikannya semakin dihormati dan dihargai orang lain.

\subsubsection{Sikap Ramah dan/atau Terbuka (Gerasaq) \\ Ramah menurut Kamus Besar}

Bahasa Indonesia (KBBI) adalah baik hati dan menarik budi bahasa; manis tutur kata dan sikapnya (1996: 1124). Sementara itu, terbuka adalah tidak disembunyi-bunyikan atau tidak dirahasiakan (1996: 222). Kedua sikap atau sifat ini bisa saling memengaruhi satu sama lain. Keduanya dapat muncul secara bersamaan ketika diaplikasikan sebagai sebuah sikap atau perilaku di masyarakat. Ketika orang ramah, pada saat itu juga bisa terbuka dan menampilkan keadaan dan keberadaan diri apa adanya sebagai seorang individu.

Fakta ini sebenarnya terjadi pada orang Sasak. Orang Sasak umumnya bersikap ramah dan terbuka, bahkan mudah memercayai orang lain dalam bergaul. Hal ini merupakan sifat/karakter dasar. Mereka akan dengan mudah menerima dan menyambut kehadiran seorang tamu dengan terbuka. Menyuguhi tamu dengan minuman (kopi) dan rokok atau nginang adalah kebiasaan orang Sasak, terutama di daerah pedesaan. Tamu yang dimaksud adalah tamu yang baik, bukan tamu yang jahat. Setelah itu, pemilik rumah akan dengan terbuka memberi informasi atau berbicara dengan tamu tersebut. Hal itu dikarenakan orang Sasak berciri khas lomboq, yaitu bersikap lurus dan apa adanya. Lebih tepat bisa dikatakan“ apa yang dilihat, itulah yang didapat atau dirasakan" (what you see what youget). Artinya, orang Sasak relatif lebih mudah percaya pada orang. Oleh karena itu, orang Sasak sebenarnya tidak bisa berbasa-basi. Umumnya orang Sasak akan menunjukkan siapa dirinya yang sebenarnya melalui sikap keramahan yang ditunjukkan. Sikap demikian dipandang sebagai sikap terpuji dan merupakan perintah agama Islam sebagai agama yang diyakini orang Sasak.

Sehubungan dengan itu, karakter ramah dan/atau terbuka ini terlihat jelas dalam representasi tokoh-tokoh yang ada pada Kitab Indarjaya. Beberapa bukti terkait ini di antaranya sebagai berikut. Pertama, peristiwa Ki Syekh Salamudin menerima Sahi Merdan (Indarjaya). Tokoh agama ini dengan penuh keterbukaan dan keramahan menyambut Sahi Merdan yang datang menemuinya, padahal sebelumnya tidak pernah bertemu serta tidak tahu asalusul dan maksud kedatangan Sahi Merdan. Tokoh ini dengan mudah menyambut dan menerima Sahi Merdan sebagai murid. Dia 
bahkan langsung menjamu dengan makanan, minuman, dan nginang (makan sirih). Berikut ini merupakan kutipan dari peristiwa tersebut.

85. Ki Syekh Salamudin mendengar dengan perasaan sangat iba, "Di sini engkau duduk bersanding." Indarjaya berhatur sembah, naik lalu duduk bersama. Di hadapan mereka tersaji umbi dan keladi yang sudah masak direbus. "Inilah nanda makan keladi dan ubi!" Perintah sang syekh. Lalu Indarjaya permisi untuk menikmati ubi dan keladi tersebut.

86. Setelah makan, ia pun minum dan makan sirih. Sang syekh berkata pula, "Tinggallah anakku di sini, bersama berkhalwat denganku, agar kuajar engkau tertib, cara orang kepada orang Islam, agar hati yakin pasti cara berbakti kepada Tuhan, dan berbakti kepada guru kiat si pendeta alim serta takut kepada Allah. (Kitab Indarjaya, bait 85-86).

Kedua, sikap keramahan dan keterbukaan ditunjukkan juga oleh Syekh Lukmanul Hakim ketika menerima Indarjaya datang menemuinya. Meskipun tidak pernah bertemu Indarjaya atau Sahi Merdan sebelumnya, Syekh Lukman langsung menyambut, menerima, dan memercayai bahwa tamunya yang bernama Sahi Merdan adalah orang baik dan bermaksud baik hadir di rumahnya. Tidak hanya itu, orang tua tersebut langsung menganggap Sahi Merdan sebagai murid sekaligus anaknya. Bahkan, sebelum sampai di hadapan, orang tua ini meminta seseorang (Janahatip) untuk menyambutnya di luar. Sikap ini merupakan keramahan dan keterbukaan yang kemudian tercermin secara umum di masyarakat Sasak sampai saat ini. Gambaran sikap tokoh tersebut terlihat dalam kutipan berikut.

101. Silakan kanda langsung saja menghadap ayahanda!" Lalu diiringi masuk ke langgar tempat para murid Syekh Lukmanul Hakim. Paduka (Syekh Lukmanul Hakim) memberi salam dahulu, "Wahai anakku Indarjaya!" Indarjaya memberi hormat, "Wahai Syekh Lukmanul Hakim berbahagialah hamba."

110. "Duhai anakku Indarjaya, kumohon keikhlasan hatimu, agar tinggal di sini bersama ayah, jangan susahkan makan dan minum, bersama suka dan duka." Indarjaya berhatur sembah, "Hamba junjung kehendak Tuan, adapun hamba ini, sudah lama meninggalkan ibu bapak". (Kitab Indarjaya, bait 101 dan 110).

Berdasarkan dua fakta literer yang ditunjukkan secara eksplisit di dalam Naskah Indarjaya ini, jelaslah bahwa sikap atau sifat ramah dan terbuka ini merupakan 
hal yang sudah tertanam dan diajarkan jauh sebelumnya oleh para leluhur orang Sasak. Sifat dan sikap ini sebagai karakter sekaligus identitas orang Sasak yang dianjurkan dan diajarkan sejak dahulu serta perlu dan penting dipraktikkan oleh generasi orang Sasak sampai saat ini.

\section{Penutup}

Naskah Indarjaya merupakan karya sastra lama yang berkembang di masyarakat Sasak. Naskah ini terdiri atas 706 penomoran lontar dengan lima macam tembang (puh), yakni asmarandana, dangdanggula, sinom, durma, dan pangkur. Tembang-tembang tersebut muncul secara variatif, bergantung pada tensi dan/atau atmosfer cerita. Naskah ini termasuk kitab suluk yang membahas ajaran mistik atau sufisme dengan setting cerita di wilayah masyarakat Sasak Lombok. Naskah ini memberi informasi tentang a. bagaimana proses seseorang bisa menguasai ajaran sufisme, b. bagaimana seseorang menjadi sufi, dan c. kelebihankelebihan yang dimiliki oleh seorang sufi selama hidup di dunia.

Selain membahas persoalan sufisme, naskah Indarjaya ini juga memperlihatkan sejumlah karakter yang khas yang dimiliki oleh orang Sasak dan masih berkembang sampai saat ini, yaitu a. suka mengembara (ngambar); b. tekun (pacu/genem) mencari ilmu agama; c. bersikap takzim dan berbahasa santun (tindih); d. kesatria atau pemberani (wanen/merang) demi harga diri; e. rendah hati, serta f. ramah dan terbuka (gerasaq). Semua karakter yang ditemukan ini dipandang oleh masyarakat Sasak sebagai karakter baik yang selalu dijunjung tinggi dan dikedepankan oleh masyarakat Sasak. Karakter-karakter ini menjadi identitas dan kebanggan orang Sasak yang dipandang berbeda dengan suku lain di Indonesia.

\section{Daftar Pustaka}

Ahimsa-Putra, Heddy Shri. (2009). "Bahasa, Sastra, dan Kearifan Lokal di Indonesia". Makalah pada Seminar Nasional Bahasa dan Sastra II: Bahasa Indonesia dan bahasa Daerah dalam Konteks Keindonesiaan. Mataram.

Badudu dan Zain. (1996). Kamus Umum Bahasa Indonesia. Jakarta: Pustaka Sinar Harapan.

Barnet, Sylvan, et.al. (1961). Introduction to Literature. Boston; Little, Brown and Company.

Creswell, John W. (1998). Qualitative Inquiry Research Design. London: SAGE Publications

Endraswara, Suwardi. (2013). Metodologi Penelitian Sastra, Epistemologi, Model, Teori, dan Aplikasi. Yogyakarta: Pustaka Widyatama.

Fadjri, Muhammad. (2015). Mentalitas dan ideologi dalam Tradisi historiografi Sasak-Lombok pada 
Abad XIX-XX. Disertasi. Yogyakarta: FIB UGM.

Fathurrahman, Lalu Agus. (2017). Kosmologi Sasak: Risalah Inen Paer. Mataram: Penerbit Genius.

Holliday, A. (2002). Doing and Writing Qualitative Research. Great Britain: The Cromwell Press Ltd.

Hornby, A.S. (1974). Oxford Advanced Learner's Dictionary of Current English. Oxford: Oxford University Press.

Istanti, Kun Zachrun. (1985).Cerita-cerita Syekh Bagenda Mardam, Suatu Kajian Studi Pendahuluan. Depdikbud, Dirjen Kebudayaan, Proyek Penelitian dan Pengkajian Kebudayaan Nusantara.

Morrison, Geoffrey E. (1999). Sasak dan Javanese Literature of Lombok, Kertas Kerja. Leiden: KITLV, VII.

Nuriadi. 2016. Theory of Literature: An Introduction. Mataram: Arga Puji Press.

Nuriadi. (2018). Kajian Lirik Lagu 'Cilokaq' dalam Rangka Mendefinisikan Pemikiran Umum Orang Sasak. Penelitian PNBP. Universitas Mataram.

Sorenggana, Aswandikari. (2006). Konsep Tasawuf Naskah Indarjaya Sasak (Kajian Filologi dan Semiotik. Mataram: Arga Puji Press.

Strauss A dan J Corbin. (2003). Dasardasar Penelitian Kualitatif; Tata Langkah dan Teknik-teknik Teoritisasi Data (terjemahan) M. Shadiq dan Imam Muttaqien. Yogyakarta: Pustaka Pelajar.
Wacana, dkk. (1995). Hikayat Indarjaya. Departemen Pendidikan dan Kebudayaan. Direktorat Jenderal Kebudayaan, Sejarah dan Nilai Tradisional Proyek Pengkajian dan Pembinaan Nilai-nilai budaya.

Windia, Lalu Bayu. (2006). Manusia Sasak: Bagaimana Menggaulinya? Cetakan I. Yogyakarta: Genta Press.

Windia, Lalu Bayu. (1996). Kamus Besar Bahasa Indonesia. Jakarta: Pustaka Sinar Harapan. 
Cerminan Karakter Orang ... 